\title{
Semi-Formal Islamic Microfinance Institutions in Nigeria: The Experience of Al-Hayat Relief Foundation
}

\author{
Taofiki Salako \& Asif Azeez \\ Taj Solarin University of Education Ijagun, Ijebu-Ode, Nigeria \\ salakota@tasued.edu.ng, asifolatubosun@gmail.com \\ DOI: https://doi.org/10.37134/jcit.vol8.5.2018
}

\begin{abstract}
Al-Hayat Relief Foundation was established as a non-governmental organization (NGO) about seventeen years ago purposely to alleviate poverty among Nigerian Muslims. The organization claims to have adopted Islamic framework of financing. This paper assessed the economic and social impacts of the foundation on its members. It also examined the extent by which the foundation complies with the principles of Islamic economic system. Three hypotheses were designed to assess the variables and the Shariah compliance programmes of the foundation. The paper adopted a descriptive research survey method. A self-developed questionnaire was the instrument used for data collection. Descriptive analysis was used to analyze the data collected from the responses to the questionnaire. Using SPSS 2011 version package, Pearson's correlation analysis was used for the verification of null hypotheses. The findings revealed that the foundation contributes meaningfully to the economic and social well being of the people and that the programmes carried out by the foundation are shariah compliant to a reasonable level.
\end{abstract}

Keywords: Islamic Microfinance Institutions, Al-Hayat Relief Foundation

\section{INTRODUCTION}

Microfinance institutions according to central bank of Nigeria (Central Bank of Nigeria, 2013) are well structured organizations that provide financial services such as savings, loan and other credit facilities to poor and low income earners and their micro businesses. These institutions are grouped into three categories via: formal, semi-formal and informal microfinance institutions. Examples of formal institutions include microfinance banks, insurance firms and finance companies that are owned by either public or private individuals. Examples of semi-formal include credit unions, cooperative societies and relief organization such as Al- Hayat Relief Foundation. Informal microfinance institutions are self-help groups and individual collectors.

In Nigerian, government set aside a body that serves as a supervisor and regulator of such formal institution i.e. Central Bank of Nigeria. Adewale and Mustafa (2013) however opined that Islamic Microfinance alternative is not existing in Nigeria. They even suggest having various small and local NGOs at least to start with. This position is not a true picture of what is happening in Nigeria. Although, Ilorin city used as research centre by Adewale and Mustafa may be misleading; because Islamic Microfinance Institutions in form of cooperative societies are predominant in the South-Western Nigeria. Notwithstanding, there is a branch of Al-Hayat Relief Foundation inaugurated on the $27^{\text {th }}$ of June, 2010 that has its secretariat at 24, Kamaldeen street, Opposite Borehole Tank, Okekere, Ilorin, Kwara state. This work is intended to correct the claim of non-existence of Islamic Microfinance Institutions in Nigeria, as well as establish their economic and social 
impact particularly that of Al-Hayat Relief Foundation. The study is anchored on three hypotheses that serve as the basis for the three research questions.

\section{Hypotheses}

i. There is no significant impact of Al-Hayat Relief Foundation on the standard of living of its members since after joining the foundation.

ii. There is no significant improvement in the social standard of members of Al-Hayat compared to when they were not members.

iii. There is no significant awareness of Islamic Economic theories among Al-Hayat members.

\section{Research Questions}

i. Is there any economic impact of Al-Hayat Relief Foundation on its members?

ii. Is there any social impact of Al-Hayat Relief Foundation on its members?

iii. To what extent do the schemes of Al-Hayat Relief Foundation comply with Shariah based economic system?

\section{Statement of the Problem}

Having a formal Islamic financial institution is still problematic in Nigeria due to legal, political and technical issues. This led to the formation of many Islamic informal and semiformal financial institutions in order to alleviate poverty among the Muslims. How far these institutions are performing to reduce poverty as well as strict adherence to the principles of Islamic finance is not empirically clear and that forms the basis for this paper. Al-Hayat Relief Foundation has been chosen as a case study.

\section{ISLAMIC MICROFINANCE INSTITUTIONS IN NIGERIA}

Adepoju (2014) describes Islamic Microfinance Institutions presently in Nigeria as cooperative societies that based their structures and activities on Islamic concept of brotherhood (Ikhwah), cooperation (ta'wwun) and unity (ittihad). He further differentiated between Western oriented and Islamic oriented cooperative societies. While Islamic cooperative system frowns at taking interest, encourages ethical investment and asset-backed financing, the western system gives no consideration on those aspects.

Noibi (2014) is also of the opinion that coming together of Muslims as cooperative societies would add some values to their livings as decent Muslims in accordance with the teachings of Islam. He opines that poverty would be reduced among the Muslims as they would have access to fund that would enhance their income and improve their standard of livings.

Researchers discover many Islamic cooperative societies among which some registered with the government and many do not. Among the registered ones that can be described as semi-Formal Islamic Microfinance institutions are Al-Hayat Relief Foundation, As-Salam Development Foundation, Al-Ansar Muslim Foundation, Da'wah Front Multipurpose Cooperative Society, Albarkah Islamic Cooperative (Oyesanya, 2013). 


\title{
Al-Hayat Growth and Development
}

\author{
Branch and Membership
}

Oyesanya (2013) studies Islamic microfinance institutions in Ogun State among which AlHayat Relief Foundation is leading. He submits that Al-Hayat was established to champion the course of Islamic economic system by financing its registered members on interest-free basis and other welfare packages. He records that Al-Hayat has spread across six states in Nigeria, namely, Ogun, Lagos, Osun, Oyo, Ondo and kwara States. He puts the number of branches to be forty and total population of the members to be six thousand.

Presently however, information released from Al-Hayat secretariat at no 18A Olisa street, Ijebu-Ode stated that the number of branches has increased to fifty-six. Member's population has also increased to eight thousand $(8,000)$. This shows that Al-Hayat rapidly grows in terms of number of branches and membership. It indicates that if Al-Hayat is properly managed, its future is brighter.

\section{Al-Hayat Organogram and Schemes}

Organogram of Al-Hayat Relief Foundation according to Salako, Adepoju and Azeez (2013) hierarchically recognizes Allah as Supreme Being upon who board of trustees is answerable. Then, the board of trustees, followed by national executive council (NEC), followed by branch executive (BEC), then the grass root members.

Azeez (2012) records the foundation's schemes to include interest free loan (qarda hassan), life insurance (takaful), mark-up (murabaha) business, partnership (musharakah) business, trading (tijarah), collection and distribution of zakat (compulsory alms giving) and sadaqah (voluntary gifts and donations), hajj and Umrah services and housing schemes for members.

\section{Al-Hayat Microfinance Bank Ltd}

As part of development, Al-Hayat Relief Foundation in 2014 achieved one of its goals, as it owns a unit of microfinance bank (Al-Hayat Microfinance Bank Ltd). Shares allotted to establish the bank was thirty million at one Naira per share. In his speech at the opening ceremony of the bank, the president (Amir) of the foundation said:

"Today's event is another step by the foundation to expand its micro credit agenda not only to its members but to other Nigerians irrespective of their religious affiliations".

The bank is situated at 22, Folagbade Street, Ibadan Road, Ijebu-Ode where it is still battling with its teething problems viz a viz operation of Islamic principles and products under conventional license. However, in an interview held with the Managing Director/Chief Executive Officer of the bank, Mr. S.A. Oresajo, the bank is getting stronger on daily basis and could change to full fledge Islamic Bank in the nearest future. He 
remarked also that the very first set of the beneficiaries were non-Muslims. This indicates that the bank transacts businesses without religious bigotry.

\section{RESEARCH METHODOLOGY}

\subsection{Area of Study}

Al-Hayat Relief Foundation formed the area of study for this research. It was chosen because it has a number of branches spread across South West Nigeria and has a reasonable large number of members whose job areas cut across civil servants, traders, artisans and the likes.

\subsection{Population of the study}

The study covered five states in the South western geopolitical zone of Nigeria namely Ogun, Lagos, Oyo, Osun and Ondo States. The 8,000 members of Al-Hayat Relief Foundation served as population of the study. The descriptive research design of a survey type was used in this study. In order to accomplish the objectives of this study, primary data were collected through self-developed questionnaire.

\subsection{Sample and Sampling Technique}

The samples used in this study were those members who have understood the principles and programmes of the foundation and have also benefited from the schemes of the organization. A total of five hundred (500) members were involved concentrating in ten branches of the foundation. Fifty (50) members were randomly selected from the branches to provide information about the programmes and activities of the foundation.

\subsection{Method of Data Collection and Technique of Analysis}

The instrument used for data collection was a self prepared questionnaire. The questionnaire contained twenty (20) items which were distributed to ten (10) branches of Al-Hayat. Members were randomly selected across the aforementioned states; only members that have joined the foundation for at least three years were purposely selected as respondents in each branch. The Branches of Al-Hayat hold their meetings once in a month; on these meeting days, the researchers with the help of the Branch executive officers gave out questionnaires to only fifty (50) members in the branch to fill the questionnaires and return on the spot. Statistical Package Analysis for Social Sciences (SPSS) was used to analyze the data collected.

\section{Data Presentation and Discussion of Findings}

This study centred on Al-Hayat Relief Foundation members as respondents. 500 members from 10 branches were involved in the study. Out of 500 questionnaires given out, 411 were retrieved. From this number, 401 were fully filled while 10 were partially filled. The researchers dropped the ten that were partially filled because they were less to $70 \%$ level of completion and according to Sekaran (2007), any questionnaire that is less to $70 \%$ completion filled should be discarded. 
Consequently, 401 questionnaires were analyzed. Descriptive analyses of the demographic data revealed that 250 (62 \%) males and 151 (38\%) females were the respondents who participated in the study. This gives an indication that males are more in number than females in the areas of focus for this study. This is represented in table 1 below:

Table 1. Male and female respondents

\begin{tabular}{rlrrrr}
\hline & & Frequency & Percent & Valid Percent & Cumulative Percent \\
\hline Valid & Male & 250 & 62.3 & 62.3 & 62.3 \\
& Female & 151 & 37.7 & 37.7 & 100.0 \\
& Total & 401 & 100.0 & 100.0 & \\
\hline
\end{tabular}

The rerspondents' ages range spread between 20 - 30 years, 43 in number (11\%), 31 - 40, 200 in number (50\%), 41 - 50 years, 107 in number ( $27 \%), 51$ - 60 years, 46 in number $(12 \%)$ and 61 years and above, 5 in number $(1 \%)$. This is represented in table 2 below:

Table 2. Years or ages of respondents

\begin{tabular}{rlrrrr}
\hline & Frequency & Percent & Valid Percent & Cumulative Percent \\
\hline Valid & 20 - 30 years & 43 & 10.7 & 10.7 & 10.7 \\
& 31- 40 years & 200 & 49.9 & 49.9 & 60.6 \\
& 41 - 50 years & 107 & 26.7 & 26.7 & 87.3 \\
& 51 - 60 years & 46 & 11.5 & 11.5 & 98.8 \\
61 years plus & 5 & 1.2 & 1.2 & 100.0 \\
Total & 401 & 100.0 & 100.0 & \\
\hline
\end{tabular}

Looking at the age range between 31 years and 60 years amounted to 353 in number which indicated that people of active age and maturity over $90 \%$ of the population constituted the majority of the membership of the foundation.

As per the qualifications of the respondents, 94 of them, $(23 \%)$ possessed senior certificate examination results. 111 of the respondents, $(28 \%)$ possessed National Diploma and National Certification of Education results. 165, (41 \%) possessed Higher National Diploma and first degree certificates while 31 of them $(8 \%)$ possessed higher degree certificates.

Concerning their professions, 89 of the respondents (22\%) were civil servants, 124 (31\%) were teachers, 35 (9\%) were artisans while 153 (32\%) were into personal business. This showed that the membership of the foundation spread among different job descriptions which further portrayed that the foundation embraced all groups of people into the foundation. The foundation as observed from the study is not meant for a particular group or class of workers and this is shown in table 3 as follow: 
Table 3. Job Description of respondents

\begin{tabular}{llrrrr}
\hline & Frequency & Percent & Valid Percent & Cumulative Percent \\
\hline Valid & Civil Servant & 89 & 22.2 & 22.2 & 22.2 \\
& Teacher & 124 & 30.9 & 30.9 & 53.1 \\
& Artisan & 35 & 8.7 & 8.7 & 61.8 \\
& Business & 153 & 38.2 & 38.2 & 100.0 \\
& Total & 401 & 100.0 & 100.0 & \\
\hline
\end{tabular}

Discussion of the Findings

Variable 1: Economic Impacts

Items 1 to 6 were targeted at measuring the variable economic impacts among members. Setting the Shariah compliance as the dependent variable, these items were further transformed and using Pearson's Correlation analysis, it established that the economic impact met the significant level of 0.000 indicating that the foundation's schemes and programmes contributed significantly to the economic upliftment of the foundation members. This decision was arrived at due to the fact that responses from members confirmed that their economic status improved due to the schemes of Al-Hayat Relief Foundation. The analysis is illustrated in table 4 below:

Table 4. Correlations

\begin{tabular}{llrr}
\hline & & shariahcompli & economicimpac \\
\hline Pearson Correlation & Shariahcompliance & 1.000 & .460 \\
& Economicimpact & .460 & 1.000 \\
Sig. (1-tailed) & Shariahcompliance &. & .000 \\
& Economicimpact & .000 &. \\
$\mathrm{~N}$ & Shariahcompliance & 401 & 401 \\
& Economicimpact & 401 & 401 \\
\hline
\end{tabular}

Variable 2: Social Impact

Items 7 to 12 centred on measuring the social impact on members. Also using the Shariah compliance as the dependent variable, these items were transformed and with Pearson's Correlation analysis, it confirmed that the social impact equally met the significant level of .000 showing that the foundation's schemes and programmes contributed significantly to the social status of the foundation members. This is portrayed in the table 5 of the analysis below:

Table 5. Correlations

\begin{tabular}{llrr}
\hline & & shariahcompliance & socialimpact \\
\hline Pearson Correlation & Shariahcompliance & 1.000 & .335 \\
& Socialimpact & .335 & 1.000 \\
Sig. (1-tailed) & Shariahcompliance &. & .000 \\
& Socialimpact & .000 &. \\
& Shariahcompliance & 401 & 401 \\
& Socialimpact & 401 & 401 \\
\hline
\end{tabular}


Variable 3: Shariah Compliance

Items 13 to 20 focused on measuring the Shariah compliance of the activities of the foundation. With the same analysis approach applied to the earlier two variables, the principles and programmes of the foundation were found to be in line with the provisions and guidelines of the Shariah, This is further illustrated in table 6 below:

Table 6. Correlations

\begin{tabular}{llrr}
\hline & & Shariahcompliance & hypothesis1 \\
\hline Pearson Correlation & Shariahcompliance & 1.000 & .460 \\
& hypothesis1 & .460 & 1.000 \\
Sig. (1-tailed) & Shariahcompliance & .000 & .000 \\
N & hypothesis1 & 401 & 401 \\
& Shariahcompliance & 401 & 401 \\
\hline
\end{tabular}

The researchers of this study formulated three hypotheses which were verified to further ascertain and concretize their findings that Al-Hayat Relief Foundation had economic and social impacts on members and that the foundation followed Shariah principles in carrying out its activities among members. These were:

Hypothesis 1: There is no significant impact on the standard of living of Al-Hayat members since after joining the foundation.

Using Pearson's Correlation analysis, the first hypothesis is rejected because the significant value recorded is 0.000 . The significant value for the Analysis of Variance is .000 while the $\mathrm{p}$ value for correlation coefficient is 0.002 . The null hypothesis is thus rejected indicating that there has been significant impact in the standard of living of members since after joining the foundation. This finding justifies the fact that Al-Hayat members have access to funds to acquire assets and to develop their businesses. This analysis is presented in the table 7 below:

Table 7. Analysis of hypothesis 1

\begin{tabular}{|c|c|c|c|c|c|c|c|}
\hline \multirow{2}{*}{\multicolumn{2}{|c|}{ Model }} & \multicolumn{2}{|c|}{ Unstandardized Coefficients } & \multicolumn{2}{|c|}{ Standardized Coefficients } & \multirow[t]{2}{*}{$t$} & \multirow[t]{2}{*}{ Sig. } \\
\hline & & B & Std. Error & Beta & & & \\
\hline \multirow[t]{2}{*}{1} & (Constant) & 1.752 & .140 & & & 12.550 & .000 \\
\hline & economicimpact & .453 & .044 & & .460 & 10.338 & .000 \\
\hline a. & Dependent Variab & shariahcon & $\begin{array}{l}\text { cee } \\
\text { ull hypothesis }\end{array}$ & jected) & & & \\
\hline
\end{tabular}

Hypothesis 2: There is no significant improvement in the social standard of members of Al-Hayat compared to when they were not members.

As regards the social impact on members, hypothesis 2 equally recorded a p value of 0.000 . Analysis of variance recorded was 0.000 while the correlation coefficient recorded was 0.002. Following the significant $p$ values recorded, hypothesis 2 is rejected showing that 
there has been a significant improvement in the social standard of members after joining the foundation. This may not be too strange because there seems to be a positive correlation between economic standard and social status. These too seem to go hand in hand. Hence, there is the possibility of matching social status with economic standard. Analysis of this finding is presented in table 8 below:

Table 8. Analysis of hypothesis 2

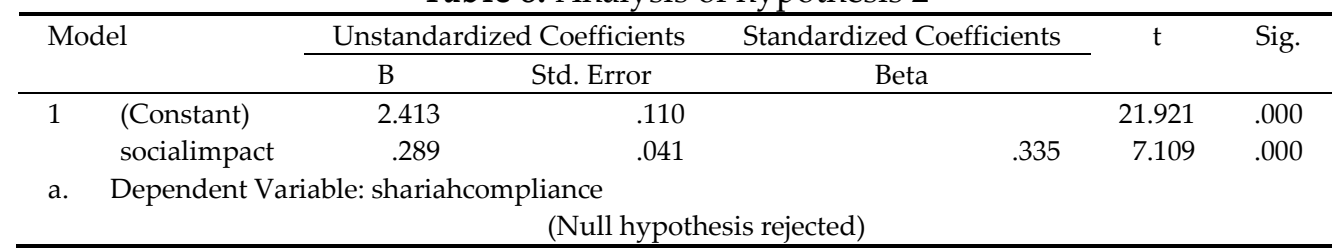

Hypothesis 3: There is no significant awareness of Islamic economic theories among AlHayat members.

For hypothesis 3, which focused on the Shariah compliance of the schemes and programmes of the foundation, the Pearson's correlation $p$ value recorded was 0.000 while the correlation coefficient was also 0.000 , thereby making the null hypothesis to be rejected indicating that there is significant awareness of Islamic Economic Theories among AlHayat members. This study showed that even though majority of people in this area lack the knowledge of Islamic financial theories but the moment they become Al- Hayat members, they are introduced to some basic Islamic financial transactions and terminologies which they get used to with time. Secondly, the analysis confirmed that AlHayat does not approve or release funds to members to carry out un-Islamic businesses. The study also established the fact the principle of justice and equality is upheld by the foundation among the leaders and the members. Table 10 below projects the result of hypothesis 3.

Table 9. Analysis of hypothesis 3

\begin{tabular}{lccr}
\hline Model & & & hypothesis3 \\
\hline 1 & Correlations & hypothesis3 & 1.000 \\
& Covariances & hypothesis3 & .000 \\
a. & Dependent Variable: shariahcompliance & \\
& & (Null hypothesis rejected)
\end{tabular}

Following these findings, there is no doubt that Al-Hayat Relief Foundation contributes meaningfully to the economic and social life of members within the communities where it operates. This contribution is not however limited to members alone as it was observed from the study that non-members too benefit from Zakat and Sadaqah scheme of the foundation. For instance, Item 10 focused on Zakat and Sadaqah scheme of the foundation. And in response to this item, 374 respondents (93\%) agreed that non-members too benefit from the scheme. This is an indication that certain programmes of the foundation accommodate some non-Muslims. Response to item 10 is shown in figure 1. 


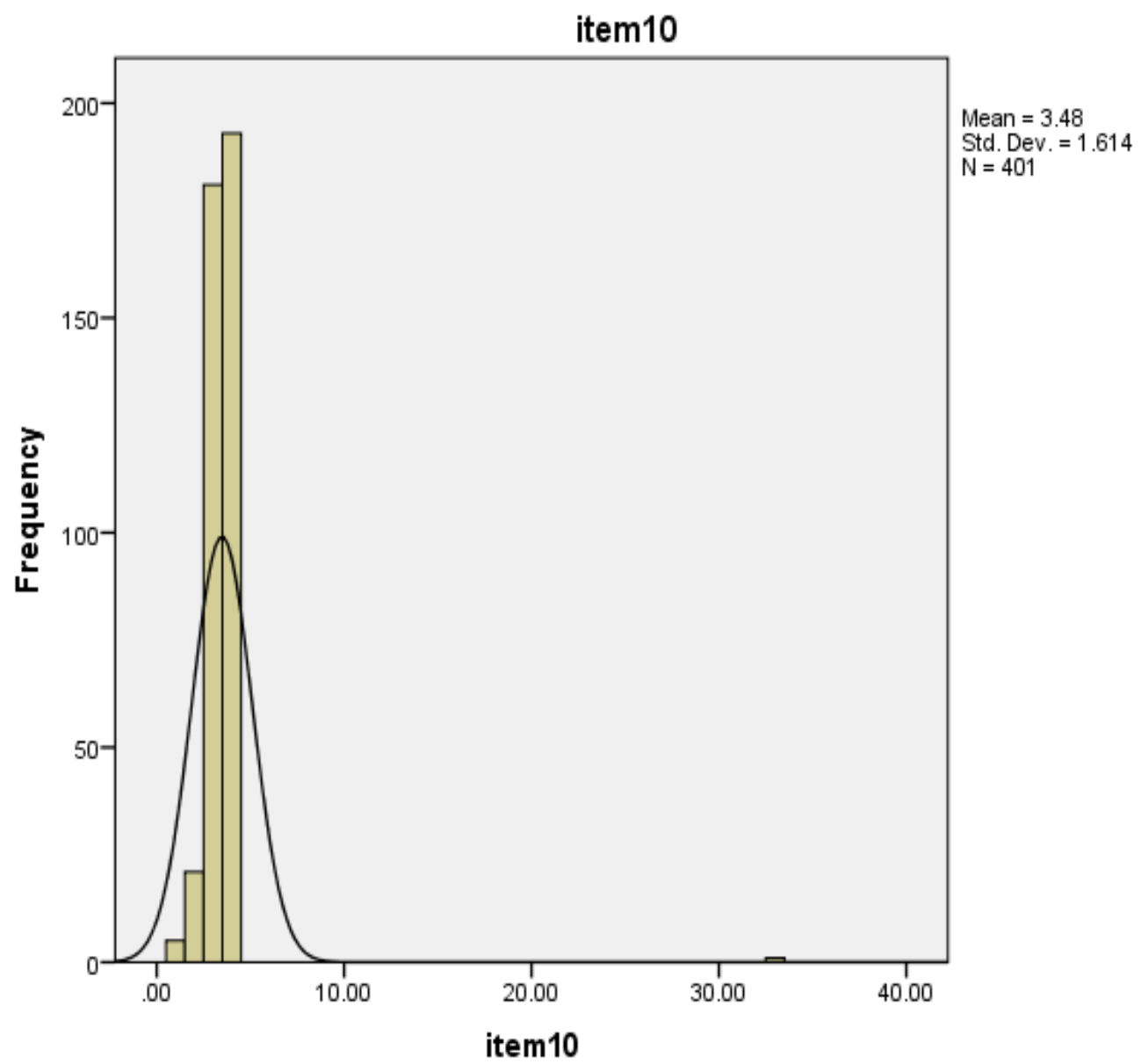

Figure. 1 Responses on Sadaqah benefits to members and non-members

Ninety-three (93\%) of respondents agreed that non-members also benefit from job opportunities created by the foundation. Item 7 centres on the creation of jobs for members and non-members. 317 (80\%) of respondents agreed that Al-Hayat creates jobs for Muslim and non-Muslims alike. There response is represented in figure 2 below. 


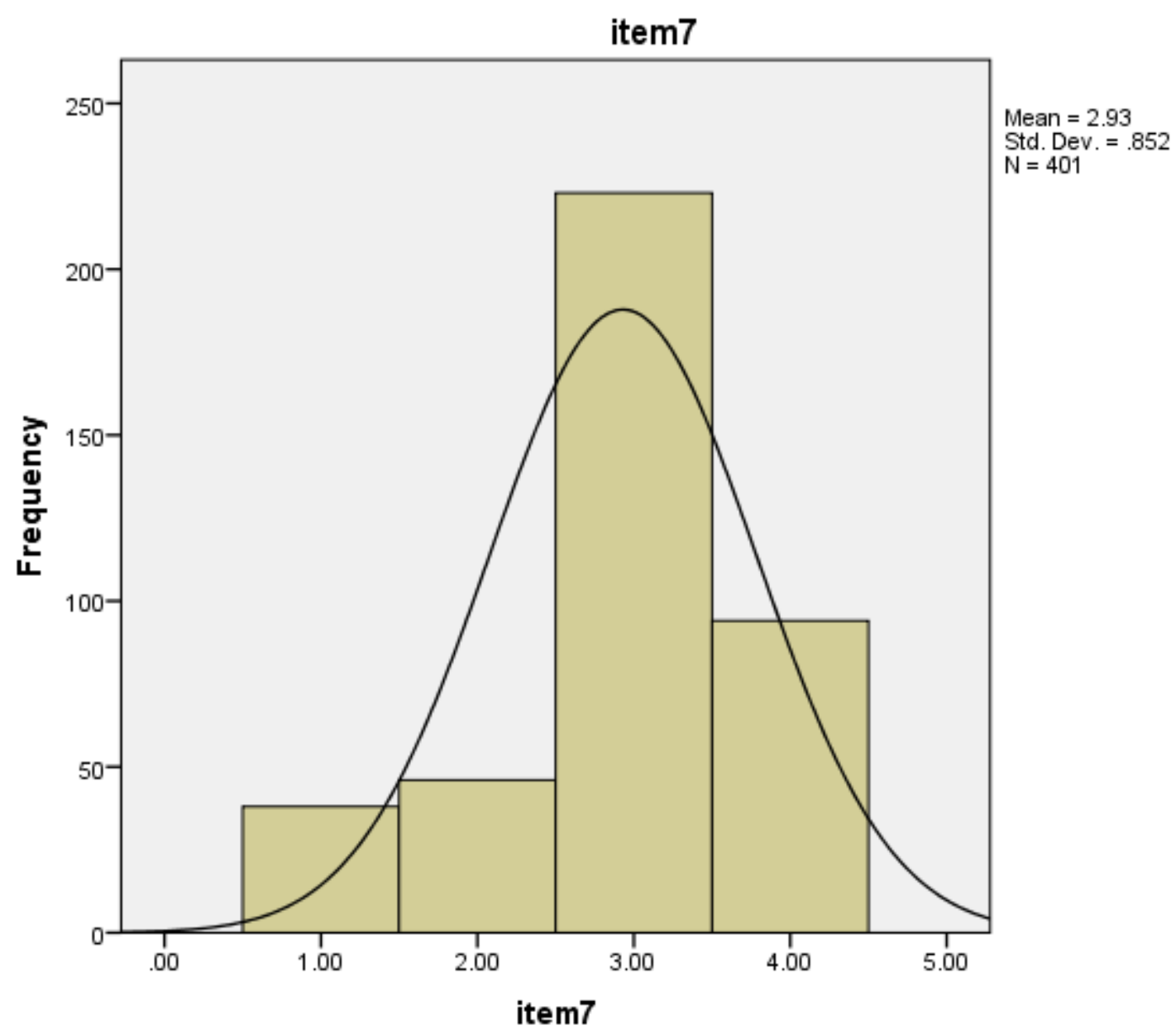

Figure 2. Responses on creation of jobs for Members and Non-members

\section{CONCLUSION AND RECOMMENDATIONS}

Al-Hayat Relief Foundation is a pioneer organization that champions the course of Islamic Economic system in this part of the world. This foundation no doubt contributes meaningfully to the economic and social well being of the people in this locality as it has been established in this study. The foundation has been able to create awareness among the citizenry and there is the certainty that Islamic financial theories can thrive in this environment and that our people Muslims and non-Muslims alike will be willing to patronize the schemes and that the proceeds of this foundation are overwhelming and encouraging.

\section{RECOMMENDATIONS}

There is the need for the training of more personnel in the area of Islamic Financing which has constituted a cog in the wheel of progress of the activities of the foundation and which has constituted a stumbling block in the area of expansion and spread of the foundation to very distant parts of the country. It is believed that this will further help in sustaining the laudable programmes of Al-Hayat Relief Foundation. This will also assist other similar 
bodies grow fast and make meaningful contributions in the spiritual and social economic lives of the people. The study also recommends working together of the similar groups who have the same agenda and principles as this will make them have a formidable force to tackle some challenges.

\section{REFERENCES}

Adepoju R.I. (2014). Islamic Co-operation Arrangement as alternative to Interest-Based Co-operative schemes. A paper presented in a seminar organized by As-Salam Development foundation, at Olori Wulemotu Mosque Balogun Kuku Road, Ijebu ode, Ogun Nigeria, on the $1^{\text {st }}$ of October 2014. (Unpublished).

Adewale A.A and Mustafa D. (2013). Poverty Alleviation and Microfinance in Nigeria. The Relevance of a Maqasid Ash-shari'ah based (msb) model (K.I. Dandago, A.D Muhammad \& U.A. Oseni) in Essentials of Islamic Banking and Finance in Nigeria, Kano, Benchmark Publishers.

Azeez A.O. (2012). Achieving Effective Da'wah Through Economic Empowerment: The Case of Al-Hayat Relief Foundation, Ijebu-Ode, Nigeria. in TESSHI 2012 chapters on Humanities and Social Sciences (ed. Syazliyati Ibrahim, Nor Aslah Adzmi \& Maznah Wan Omar), Univesity Teknologi, Marra, Kedah, Malaysia. (JOHASS), Volume 13, ISSUE 13, eISSN:22790837

Central Bank of Nigeria (CBN). (2012). Microfinance certification Programme: A study Manual. The CIBN Press.

Noibi, M. (2014). Islamic Cooperative Society: It's implication To The Muslim Ummah. A paper presented in a seminar organized by As-Salam Development foundation, at Olori Wulemotu Mosque Balogun Kuku Road, Ijebu ode, Ogun Nigeria, on the $1^{\text {st }}$ of October 2014. (Unpublished).

Oyesanya O.S. (2013). The Impact of Non-Formal Islamic Microfinance Institutions on Poverty Alleviation in Ogun state, Nigeria. A master Dissertation submitted in the Department of Religious studies, Olabisi Onabanjo University, Ago-Iwoye, Nigeria.

Salako, T. A., Adepoju, R. I. \& Azeez, A. O. (2013). Prospects of Islamic Banking in Nigeria: An overview of Islamic financial theories of Al-Hayat relief foundation to grassroot economic development. Journal of Humanities and Social Sciences (IOSR) Vol 13, Issue 3, pp 39-47.

Sekaran, U. (2007). Research Methods for Business - A Skill Building Approach. Wiley India (p). Ltd. 4435/7. Ansari Road, Daryaganj, New Delhi. 110002. 


\section{Appendix}

Department of Islamic Studies,

Tai Solarin College of Education,

Omu-Ijebu.

\section{Dear Respondent,}

\section{ASSESSMENT OF THE SOCIO-ECONOMIC IMPACT OF AL- HAYAT RELIEF FOUNDATION}

This questionnaire is to be answered by members of Al-Hayat Relief Foundation only. The respondent must have joined the Foundation at least for the past three years. The questionnaire is designed to obtain information about your perception on Al-Hayat.

You are hereby requested to kindly complete this questionnaire objectively as it is believed that research work always contributes to the development of any standard organization. Please be informed, this questionnaire is purely for academic purpose and all information shall be treated confidentially.

Thanks and God bless.

\section{Signed}

Dr. A. O. Azeez \& Dr. T. A. Salako

Researchers 


\section{Section A: Biodata}

1. Date:

2. Gender: Male $\square$ Female $\square$

3. Age: $20-30 \square$ 31-40 $\square$ 41-50 $\square$ 51-60 $\square$ 61 and above $\square$

4. Your highest qualification: SSCE $\square$ NCE/OND $\square$ HND/First Degree $\square$ Higher Degree

5. Your profession: Civil servant $\square$ Teacher $\square$ Artisan $\square$ Business $\square$

6. You joined Al Hayat in the year 


\section{SECTION B}

Please assess the following items on Al-Hayat Relief Foundation and tick $(\sqrt{ })$ the extent to which you agree with them. Strongly Disagree (SD), Disagree (D), Agree (A), Strongly Agree (SA)

\begin{tabular}{|c|c|c|c|c|c|}
\hline $\mathbf{S} / \mathbf{N}$ & ITEMS & SD & D & $\mathbf{A}$ & SA \\
\hline 1. & Al-Hayat assists the poor to access funds. & & & & \\
\hline 2. & $\begin{array}{l}\text { Members of Al-Hayat acquire assets such as land, house, car, office } \\
\text { equipments etc through different schemes of the foundation }\end{array}$ & & & & \\
\hline 3. & $\begin{array}{l}\text { Members of Al Hayat have opportunity to generate more incomes } \\
\text { from their businesses than before they joined the foundation }\end{array}$ & & & & \\
\hline 4. & $\begin{array}{l}\text { Savings for future plan and target have become part and parcel of } \\
\text { members of Al-Hayat. }\end{array}$ & & & & \\
\hline 5. & $\begin{array}{l}\text { Al-Hayat can contribute meaningfully towards having formal } \\
\text { Islamic Microfinance Banks in Nigeria. }\end{array}$ & & & & \\
\hline 6. & $\begin{array}{l}\text { There is no difference in the living standard of members of Al- } \\
\text { Hayat compared to periods before they joined the foundation }\end{array}$ & & & & \\
\hline 7. & Al-Hayat creates job opportunities for people. & & & & \\
\hline 8. & Male and Female members enjoy equal opportunities in Al-Hayat. & & & & \\
\hline 9. & $\begin{array}{l}\text { Al-Hayat monthly meetings help in the social and moral } \\
\text { development of its members. }\end{array}$ & & & & \\
\hline 10. & $\begin{array}{l}\text { Zakat and Sadaqah scheme of Al-Hayat has contributed } \\
\text { meaningfully to the moral and socio-economic life of the people }\end{array}$ & & & & \\
\hline 11. & Al-Hayat participates in some hidden (garrar) transactions. & & & & \\
\hline 12. & $\begin{array}{l}\text { Al-Hayat releases funds to members that carry out businesses in } \\
\text { alcohol, piggery, pornography etc. }\end{array}$ & & & & \\
\hline 13. & $\begin{array}{l}\text { Al-Hayat promotes Islamic products like Murabahah, Musharakah, } \\
\text { Takaful etc. }\end{array}$ & & & & \\
\hline 14. & Al-Hayat applies shariah principles to all matters. & & & & \\
\hline 15. & Al-Hayat keeps proper records for all transactions. & & & & \\
\hline 16. & $\begin{array}{l}\text { To what extent will you agree that Al-Hayat invests in speculative } \\
\text { businesses e.g. gambling to make quick profits? }\end{array}$ & & & & \\
\hline 17. & Al Hayat promotes the principle of Equality and Justice (al- 'adalah) & & & & \\
\hline 18. & Leadership style of Al-Hayat is in line with Islamic principle. & & & & \\
\hline 19. & $\begin{array}{l}\text { To what extent will you agree that Al-Hayat schemes relieve } \\
\text { financial problems of members? }\end{array}$ & & & & \\
\hline 20. & Al Hayat educates its members on Islamic transactions. & & & & \\
\hline
\end{tabular}

